\title{
Neutron activation analysis for copper in biological material applied to Wilson's disease
}

\author{
G. S. FELL, HAMILTON SMITH, AND R. A. HOWIE 1 \\ From Glasgow Royal Infirmary and the Department of Forensic Medicine, \\ University of Glasgow
}

SYNOPSIS A method for the neutron activation analysis of copper in biological material is described and applied to the diagnosis and management of four cases of Wilson's disease. Results obtained for serum and urine are in agreement with values obtained by established colorimetric techniques. The method described can estimate $10^{-9} \mathrm{~g}$. copper to within $10 \%$ and this sensitivity has allowed the determination of copper from biopsy material such as liver, spleen, hair, and nail.

Radioactivation analysis is a modern technique of elemental analysis, widely applicable to the determiration of trace elements in a variety of materials. The analysis requires irradiation of samples in a nuclear reactor to induce radioactivity in the elements present. Thereafter a radiochemical separation isolates the copper activity from the mixture of radioactive elements. The estimation of copper is achieved by comparison of the copper activity of the samples with that of a standard sample containing a known weight of copper.

The advantages of the technique are sensitivity, simplicity, and specificity which can easily be demonstrated for every sample by examination of the characteristics of the radioactivity of the isolated material.

\section{ISOTOPE USED}

The activation technique in this method involves irradiation of the samples with 'slow' or 'thermal' neutrons as are available in BEPO at Harwell. The reaction taking place is neutron capture with $\gamma$ emission, i.e. the $(\mathrm{n}, \gamma)$ reaction. Natural copper is a mixture of two stable isotopes both of which undergo this reaction. The product ${ }^{64} \mathrm{Cu}$ produced by ${ }^{63} \mathrm{Cu}$ $(\mathrm{n}, \gamma){ }^{64} \mathrm{Cu}$ gives the greatest sensitivity and is therefore chosen for this investigation.

A few interfering reactions (i.e. nuclear reactions which produce copper isotopes from other elements) are possible, such as ${ }^{64} \mathrm{Zn}(\mathrm{n}, \mathrm{p}){ }^{64} \mathrm{Cu} ;{ }^{66} \mathrm{Zn}(\mathrm{n}$, p) ${ }^{66} \mathrm{Cu} ;{ }^{69} \mathrm{Ca}(\mathrm{n}, \alpha)^{66} \mathrm{Cu}$; but these are only significant if the material consists largely of the interfering element.

Received for publication 7 June 1967.

'Present address: Department of Chemistry, University of Aberdeen.
METHOD

After collection, the samples are transferred to clean polythene containers with the minimum of pre-irradiation treatment. The containers are packed in an irradiation can and then irradiated for a suitable period together with a standard copper solution. On return they are transferred quantitatively to digestion beakers with the addition of inactive carrier. Wet ashing with fuming nitric acid mineralizes the samples and equilibrates the added carrier with the activated copper. A series of precipitations is used to isolate the copper in a radiochemically pure form. The separated material is mounted on planchets, weighed to determine the chemical yield, and counted, using an end window Geiger counter. Comparison of the weight and activity (allowing for decay and counter paralysis time) of the sample with that of the copper standard gives the analytical result.

COLLECTION AND ACTIVATION OF SAMPLES Urine is collected in acid-washed plastic bottles containing concentrated hydrochloric acid $(5 \mathrm{ml}$.) as preservative. An aliquot of urine $(0 \cdot 1 \mathrm{ml}$.) is weighed in a silica ampoule which is then heat sealed.

The ampoules are $50 \mathrm{~mm}$. long, $3 \mathrm{~mm}$. bore, with $1 \mathrm{~mm}$. walls, and with a constriction about $10 \mathrm{~mm}$. from one end. The standard solution of copper is weighed and sealed in the same way and contains an accurately known weight of copper (about $1 \mathrm{mg}$.). Urine samples of this size require activation at a thermal neutron flux of $1.2 \times 10^{12} \mathrm{n} . / \mathrm{cm} .{ }^{2}$ sec. for at least 12 hours, though twice this period is sometimes required.

Serum was obtained by centrifuging whole blood collected in acid-washed glass containers. Serum is not activated in the same way as urine as radiation damage makes the material difficult to remove from the silica ampoules.

The serum ( $0.5 \mathrm{ml}$.) is dried in vacuo (two to three days). The resulting hard mass is broken up and weighed portions 
(10 mg.) are packed for irradiation in polythene ampoules (7 mm. $\times 4-5 \mathrm{~mm}$. $\times 1.5 \mathrm{~mm}$.).

Since it is known (Bowen, 1963) that each millilitre of serum will produce, on average, $0 \cdot 0718 \mathrm{~g}$. of dried material, the portion used for analysis is the equivalent of $0.1 \mathrm{ml}$. of serum. For dried serum, irradiation need only be for 12 hours at a flux of $1.2 \times 10^{12} \mathrm{n} . / \mathrm{cm} .^{2}$ second.

BIOCHEMICAL PROCESSING After return the samples are unpacked as follows:-

(a) Urine samples are pipetted from the silica tubes to suitable conical beakers (125 ml.). Pipette and silica tube are washed out with nitric acid $(5 \mathrm{ml} .50 \% \mathrm{v} / \mathrm{v})$ containing copper carrier $(1 \mathrm{ml}$. of copper sulphate, $1 \% \mathrm{w} / \mathrm{v})$. This solution is carefully evaporated to dryness and the organic material destroyed by wet ashing with nitric acid $(24 \mathrm{~N})$.

(b) For solid materials, e.g. dried serum or tissue, the material is quantitatively transferred to the beaker and wet ashed with nitric acid, the carrier copper being added afterwards. The ashed material and added carrier are dissolved in nitric acid $(0.5 \mathrm{ml} .16 \mathrm{~N})$ and the solution is washed into a centrifuge tube $(50 \mathrm{ml}$.) with water $(30 \mathrm{ml}$.).

(c) The activated standard copper solution is pipetted from its silica tube and the solution and washings are diluted to $10 \mathrm{ml}$. and this solution $(1 \mathrm{ml}$.), carrier copper $(1 \mathrm{ml}$.$) , nitric acid (0.5 \mathrm{ml}$.), and water $(30 \mathrm{ml}$.) are placed in a centrifuge tube.

The remaining steps are identical for all types of material. To the solution in the centrifuge tube are added manganese nitrate, cobalt nitrate, and ammonium dihydrogen orthophosphate $(0.5 \mathrm{ml}$. of $10 \%$ solutions of each salt) to minimize the co-precipitation of interfering radioactivity. The copper is separated from the bulk of the activity as a precipitate of cuprous thiocyanate by the addition of sodium sulphite $(1 \mathrm{ml} .20 \% \mathrm{w} / \mathrm{v})$ and potassium thiocyanate $(3 \mathrm{ml} .20 \% \mathrm{w} / \mathrm{v})$. The precipitated material is coagulated by heat on a boiling water bath and spun down. The washed precipitate is dissolved in nitric acid $(0.1 \mathrm{ml} .10 \% \mathrm{w} / \mathrm{v})$. Ammonium dihydrogen phosphate solution $(0.5 \mathrm{ml} .16 \mathrm{~N})$ and ferric chloride solution $(0.5 \mathrm{ml}$. $10 \% \mathrm{w} / \mathrm{v})$ are added. The solution is diluted and calcium chloride $(0.15 \mathrm{ml} .10 \% \mathrm{w} / \mathrm{v})$ is added. The dropwise addition of concentrated ammonium hydroxide results in the precipitation initially of calcium phosphate, followed by ferric hydroxide. Copper is retained in solution by the addition of a further quantity of ammonium hydroxide. Calcium still in solution is precipitated by the addition of sodium carbonate solution $(3 \mathrm{ml} .18 \% \mathrm{w} / \mathrm{v})$. The precipitate is coagulated by boiling, and the solution, now free from activities which might interfere in successive steps, is filtered off. The intense colour of the cuprammonium ion is discharged by the addition of acetic acid (17 N) and the solution made slightly acid by the addition of nitric acid $(0.5 \mathrm{ml} .16 \mathrm{~N})$. Copper thiocyanate is precipitated as before.

The washed precipitate is again dissolved in concentrated nitric acid and the solution diluted. The $p \mathrm{H}$ is adjusted to $4 \cdot 5-5$ by adding sodium hydroxide solution $(5 \% \mathrm{w} / \mathrm{v})$ till a precipitate just forms. The solution is acidified with nitric acid $(0.2 \mathrm{ml} .16 \mathrm{~N})$. The addition of quinaldic acid $(2 \mathrm{ml} .3 \% \mathrm{w} / \mathrm{v})$ to the hot solution precipitates copper quinaldate. This is washed with water and acetone and transferred as a slurry in acetone to an aluminium planchet. Evaporation of the acetone by an infra-red lamp is followed by weighing the precipitate, and the activity determination with an end-window Geiger counter. The purity of this preparation is checked by estimating the half-life of the separated material and by examining the gamma spectrum.

Comparison of the weights and activities recovered from the samples and the standard, after correction for decay and counter paralysis time, gives the copper content of the sample.

ACCURACY AND SENSITIVITY OF THE METHOD Using a thermal neutron flux of $1.2 \times 10^{12}$ n.cm. ${ }^{2} \mathrm{sec}$. and a 24 hour irradiation time, it is possible to estimate $10^{-9} \mathrm{~g}$ of copper with an accuracy of better than $10 \%$. This compares favourably with the classical methods described by Butler and Newman (1965) and Zak (1958).

This degree of sensitivity and precision can be readily demonstrated by the analysis of aqueous standard solutions of copper. Copper present in urine can be estimated with a similar degree of precision as is shown in the following recovery experiment.

\begin{tabular}{llll} 
Sample & $\begin{array}{l}\text { Copper Added } \\
(\mu \mathrm{g} . / \mathrm{ml} .)\end{array}$ & $\begin{array}{l}\text { Copper } \\
\text { Concentration } \\
(\mu \mathrm{g} . / \mathrm{ml} .)\end{array}$ & $\begin{array}{l}\text { Copper Found } \\
(\mu \mathrm{g} . / \mathrm{ml} .)\end{array}$ \\
\hline $\begin{array}{l}\text { Untreated urine } \\
\begin{array}{l}\text { Urine with added } \\
\text { copper (A) }\end{array}\end{array}$ & nil & - & 0.56 \\
$\begin{array}{l}\text { Urine with added } \\
\text { copper (B) }\end{array}$ & 0.70 & 1.26 & 1.30 \\
& 2.80 & 3.36 & 3.26 \\
& & & 3.12
\end{tabular}

Estimation of copper in serum activated after drying in vacuo To prove precision and accuracy for serum analysis, samples were prepared with added copper. Analyses were attempted on serum with and without added copper where activation was performed on liquid samples $(0 \cdot 1 \mathrm{ml}$.) in the silica ampoules. The irradiation damage to the serum made it necessary to add the complete silica tube to the digestion mixture and external contamination invalidated the results. This could be avoided by thoroughly cleansing the ampoules before opening them but the alternative procedure of analysing dried serum was adopted and results obtained in this way are as follows.

\begin{tabular}{llllll} 
Sample & $\begin{array}{l}\text { Copper Added } \\
(\mu \mathrm{g} / \mathrm{ml} .)\end{array}$ & $\begin{array}{l}\text { Total Concen- } \\
\text { tration of } \mathrm{Cu} \\
(\mu \mathrm{g} . / \mathrm{ml} .)\end{array}$ & $\begin{array}{l}\text { Copper Found } \\
(\mu \mathrm{g} . / \mathrm{ml} .)\end{array}$ \\
\hline $\begin{array}{l}\text { Pooled serum } \\
\begin{array}{l}\text { Serum with added } \\
\text { copper (A) }\end{array}\end{array}$ & - & - & 1.36 & 1.37 \\
$\begin{array}{l}\text { Serum with added } \\
\text { copper (B) }\end{array}$ & 0.70 & 2.07 & 2.06 & 2.25 \\
\hline
\end{tabular}

${ }^{64} \mathrm{Cu}$ activity recovered from chemical separation in the presence of dried serum It can also be shown that ${ }^{64} \mathrm{Cu}$ activity processed in the presence of inactive dried serum gives recreated activities (corrected for chemical yield) which are reproducible to within $2 \%$, as can be seen from the following results.

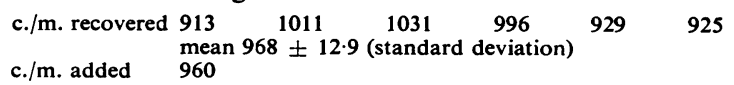


The analytical precision for solid material is shown by the analysis of a biological standard prepared by Bowen (1965). This material is kale which is dried and homogenized under carefully controlled conditions. Values found for a series of 11 analyses are as follows:-

Range $4.00-5.01 \mu \mathrm{g} . / \mathrm{g}$., median 4.30 , mean $4.41 \mu \mathrm{g} . / \mathrm{g}$. and standard deviation $\pm 0.34 \mu \mathrm{g} . / \mathrm{g}$. $(7 \cdot 7 \%)$. Bowen (1965) quotes a value of $4 \cdot 4 \mu \mathrm{g} . / \mathrm{g}$.

The activation analysis technique, employing radiochemical separation, permits the chemical processes to be carried out on a convenient scale. The gravimetric yield determination eliminates the necessity of scrupulously quantitative transfer operations once the carrier is in equilibrium with the activated material. Because of the carrier technique used, the accidental addition of inactive copper in impure reagents, necessitating a blank correction in conventional methods, is not important. Further, the same method is applicable with trivial manipulative changes to all types of biological material.

The most significant obstacle in the technique is the presentation of samples for irradiation. The small amount of space available requires the use of samples of limited size, which is not of itself any disadvantage because of the great sensitivity but the small sample size could result in unrepresentative analyses. In urine, for example, a precipitate tends to form and this is fairly rich in copper. Analyses of urine samples before and after agitation to suspend the precipitated material do not show a discrepancy exceeding the accuracy and reproducibility claimed.

\section{RESULTS}

NORMAL VAlues These are as follows for copper in serum, urine, and tissue.

Serum copper The level of $108 \pm 9 \cdot 8 \mu \mathrm{g} . \mathrm{Cu} /$ $100 \mathrm{ml}$. serum quoted by Bearn and Kunkel (1954) appears typical for results obtained by colorimetric analysis. Bowen (1963) quotes a mean value of $113 \mu \mathrm{g}$. $\mathrm{Cu} / 100 \mathrm{ml}$. from 630 analyses performed by a variety of techniques, including activation analysis.

In the present study, sera from 10 patients thought unlikely to have abnormalities of copper metabolism were analysed and the specimens had a mean of $113 \mu \mathrm{g} . \mathrm{Cu} / 100 \mathrm{ml}$, median 105 , range 86-136, and a standard deviation of $22 \mu \mathrm{g}$. $\mathrm{Cu} / 100 \mathrm{ml}$.

Also sera from a further 10 patients were pooled and gave a value of $101.5 \mu \mathrm{g} . \mathrm{Cu} / 100 \mathrm{ml}$.

Urine copper Values quoted for colorimetric analysis of the normal urinary copper excretion are $48 \pm 16 \cdot 3 \mu \mathrm{g}$. $\mathrm{Cu} / 24$ hours (Bearn and Kunkel, 1954). No figures are available for activation analysis and a series of nine 24-hour collections were analysed and gave the following results: mean $120 \mu \mathrm{g}$. Cu/24 hours, range $30-330 \mu \mathrm{g}$. Cu/24 hours. The high values obtained were considered to be caused by contamination.

Tissue copper Samples of tissue were taken at necropsy from cases of accidental death. The irradiation was performed after the minimum ob handling. Results obtained are shown in Table I.

TABLE I

\begin{tabular}{|c|c|c|c|c|c|}
\hline \multirow[b]{2}{*}{ Liver } & $\begin{array}{l}\text { Number of } \\
\text { Specimens }\end{array}$ & \multicolumn{3}{|c|}{$\begin{array}{l}\text { ug./g. DRY WEIGHT) } \\
\text { Mean Median Range }\end{array}$} & $\begin{array}{l}\text { Standard } \\
\text { Deviatio }\end{array}$ \\
\hline & 24 & $25 \cdot 54$ & $25 \cdot 2$ & $9 \cdot 20-46 \cdot 8$ & $11 \cdot 5$ \\
\hline Spleen & 24 & 6.83 & 6.08 & $3 \cdot 13-16 \cdot 1$ & 2.85 \\
\hline Hair & 29 & 23.09 & $19 \cdot 1$ & $7 \cdot 4-54 \cdot 5$ & $11 \cdot 7$ \\
\hline Nail & 33 & $18 \cdot 08$ & 14.9 & $3 \cdot 18-58 \cdot 2$ & $12 \cdot 1$ \\
\hline Brain & 21 & $23 \cdot 89$ & $23 \cdot 2$ & $13 \cdot 1-39 \cdot 4$ & $6 \cdot 36$ \\
\hline Breast & 3 & $4 \cdot 55$ & 3.94 & $1.35 \quad 8.36$ & 3.55 \\
\hline Stomach & 20 & $12 \cdot 55$ & $11 \cdot 0$ & $4 \cdot 50-36 \cdot 6$ & $7 \cdot 69$ \\
\hline Heart & 24 & 16.48 & $16 \cdot 3$ & $10 \cdot 10-22 \cdot 9$ & 3.68 \\
\hline Kidney & 23 & 14.90 & $13 \cdot 2$ & $5 \cdot 10-35 \cdot 7$ & 6.89 \\
\hline Lung & 21 & $9 \cdot 54$ & $9 \cdot 50$ & $4.2-15.9$ & 3.55 \\
\hline Thymus & 3 & 6.66 & $5 \cdot 24$ & $3 \cdot 25-11 \cdot 5$ & $4 \cdot 31$ \\
\hline Pectoral muscle & 22 & $5 \cdot 43$ & 4.93 & $1.95-13.8$ & $2 \cdot 82$ \\
\hline Ovary & 11 & $8 \cdot 12$ & $7 \cdot 0$ & $3 \cdot 1-16 \cdot 5$ & $4 \cdot 17$ \\
\hline Pancreas & 29 & $7 \cdot 38$ & $5 \cdot 79$ & $2 \cdot 4-20$ & $4 \cdot 65$ \\
\hline Adrenal & 18 & $7 \cdot 36$ & $5 \cdot ? 4$ & $1 \cdot 14-28.9$ & 6.94 \\
\hline Aorta & 25 & $6 \cdot 69$ & $6 \cdot 30$ & $2.4-21.9$ & 3.93 \\
\hline Bone & 18 & $4 \cdot 24$ & 2.94 & $0.85-11.8$ & 3.43 \\
\hline Prostate & 9 & 6.48 & 6.58 & $1.76-11.0$ & $2 \cdot 80$ \\
\hline Thyroid & 24 & 6.05 & $6 \cdot 37$ & $1.63-17.5$ & 3.22 \\
\hline Uterus & 13 & 8.44 & 7.05 & $3.47-25.2$ & 6.02 \\
\hline Skin & 10 & 1.98 & $1 \cdot 76$ & $0 \cdot 29-5 \cdot 40$ & 1.69 \\
\hline
\end{tabular}

Only some tissue sites were accessible in the cases: of Wilson's disease studied, but the values given serve as reference when such material is available at necropsy.

APPLICATION TO WILSON'S DISEASE Clinical featuresof the cases are as follows:-

Case 1 W.S., aged 14, male, chronic liver disease. Kayser Fleischer corneal rings, penicillamine therapy unsuccessful, splenectomy performed.

Case 2 T.F., aged 11, male, speech difficulty, limb spasticity, chronic liver disease. Clinical improvement on: penicillamine therapy.

Case 3 I.F., aged 5, female, sibling of case 2, clinicallyo normal, abnormal L.F.T.s. Prophylactic penicillamine therapy established.

Case 4 S.W., aged 14, male, case previously diagnosed. Ascites, Kayser Fleischer rings reported, L.F.T.s ab- $\rightarrow$ normal. Clinically improved on penicillamine therapy.

Case 5 M.McG., aged 21, female, chronic liver disease. Eventual diagnosis of congenital hepatic fibrosis. Ur

The results obtained from these cases are given in Tables II, III, and IV.

\section{DISCUSSION}

The serum copper levels found by activation analysis? in the four cases of Wilson's disease described hado a mean value of $46.5 \mu \mathrm{g}$. Cu/100 ml. which is in? accord with the low caeruloplasmin content also found. In addition, this figure is comparable with $a \frac{\mathrm{Q}}{\square}$ report of $60 \pm 15 \cdot 4 \mu \mathrm{g}$. $\mathrm{Cu} / 100 \mathrm{ml}$. for serumo copper in Wilson's disease obtained by colorimetric 
TABLE II

SERUM COPPER

\begin{tabular}{lll} 
& $\begin{array}{l}\text { Serum } \mathrm{Cu} \\
(\mu \mathrm{g} . / 100 \mathrm{ml} .)\end{array}$ & $\begin{array}{l}\text { Caeruloplasmin } \\
(\mathrm{mg} . / 100 \mathrm{ml} .)\end{array}$ \\
\hline Case 1 & $43 \cdot 7$ & $3 \cdot 0$ \\
Case 2 & $39 \cdot 0$ & $3 \cdot 6$ \\
Case 3 & 27 & $3 \cdot 4$ \\
Case 4 & 77 & $8 \cdot 0$ \\
Case 5 & - & $29 \cdot 0$
\end{tabular}

Estimated by immunoassay (normal range $18-36 \mathrm{mg} . / 100 \mathrm{ml}$.) using the Hyland immuno plate.

TABLE III

URINE COPPER ( $\mu \mathrm{g} . / 24$ HOURS)

\begin{tabular}{llll} 
& & Before Penicillamine & After Penicillamine \\
\hline Case 1 & W.S. & 520 & $1,450,960,1,810$ \\
Case 2 & T.F. & 785 & $3,140,2,960,3,800$ \\
Case 3 & I.F. & 240 & $430^{1}$ \\
Case 5 & M.McG. & 58 & \multicolumn{1}{l}{}
\end{tabular}

${ }^{1}$ Obtained by colorimetric analysis.

TABLE IV

TISSUE COPPER $(\mu \mathrm{g} . / \mathrm{g}$.)

\begin{tabular}{|c|c|c|c|c|c|}
\hline & & Hair & Nail & Spleen & Liver \\
\hline Case 1 & W.S. & - & - & 7.09 & 145 \\
\hline Case 2 & T.F. & $14 \cdot 8$ & $17 \cdot 7$ & & \\
\hline Case 3 & l.F. & $19 \cdot 1$ & $34 \cdot 4$ & - & - \\
\hline Case 4 & S.W. & $22 \cdot 2$ & $9 \cdot 45$ & - & - \\
\hline Case 5 & M.McG. & $21 \cdot 2$ & $11 \cdot 4$ & - & $3 \cdot 70$ \\
\hline
\end{tabular}

analysis (Bearn and Kunkel, 1954). The mean level for the other 11 members of the families studied is $87 \mu \mathrm{g} . \mathrm{Cu} / 100 \mathrm{ml}$. compared with a normal mean value of $113 \mu \mathrm{g}$. $\mathrm{Cu} / 100 \mathrm{ml}$. (Bowen, 1963).

The urine copper excretion is increased in Wilson's disease, and the mean value for the three cases studied, before treatment, is $521 \mu \mathrm{g}$. $\mathrm{Cu} / 24$ hours which is comparable to the level of $703 \pm 318 \mu \mathrm{g}$. $\mathrm{Cu} / 24$ hours reported for colorimetric analysis (Bearn and Kunkel, 1954).

The activation analysis method is of particular value when copper estimations are desired in tissues to be obtained at biopsy, since the amount of material required is so much less than that required by conventional analytical methods. Thus it has been shown that in spleen taken from a proven case of Wilson's disease the copper content of $7.09 \mu \mathrm{g}$. Cu/g. is not increased. Also in the same subject the liver content was $145 \mu \mathrm{g}$. $\mathrm{Cu} / \mathrm{g}$., showing a five-fold increase above normal. This is above the level of 100 $\mu \mathrm{g}$. $\mathrm{Cu} / \mathrm{g}$. set by Scheinberg and Sternlieb (1963) as necessary for the diagnosis of hepatolenticular disease.

In another case of severe liver disease, the demonstration on liver biopsy material of a copper content of only $3.6 \mu \mathrm{g}$. $/ \mathrm{g}$. helped to exclude a diagnosis of Wilson's disease.

The extreme economy of material offered by the method would make it very suitable for the routine determination of the copper content of liver obtained at punch biopsy. Such analyses have been advocated as a means of following the decoppering action of chelating agents (Scheinberg and Sternlieb, 1963).

For three cases of Wilson's disease the average value of copper in hair was $18.2 \mu \mathrm{g}$. $\mathrm{Cu} / \mathrm{g}$. and in nail $20.9 \mu \mathrm{g} . \mathrm{Cu} / \mathrm{g}$., which is within the normal range, thus indicating that no deposition or storage of copper is occurring, a finding in accord with other investigations (Rice and Goldstein, 1961).

\section{REFERENCES}

Bearn, A. G., and Kunkel, H. G. (1954). J. clin. Invest., 33, 400.

Bowen, H. J. M. (1963). The Elementary Composition of Mammalian Blood. (U.K.A.E.A. Rept. No. AERE-R4196). Wantage, Research Laboratory.

(1965). Activation Analysis, Principles and Applications, edited by J. M. A. Lenihan and S. J. Thomson, p. 149. Academic Press, New York and London.

Butler, E. J., and Newman, G. E. (1965). Clin. chim. Acta, 11, 452.

Rice, E. W., and Goldstein, N. P. (1961). Metabolism, 10, 1085.

Scheinberg, I. H., and Sternlieb, I. (1963). Med. Clin. N. Amer., 47 815.

Zak, B. (1958). Clin. chim. Acta, 3, 328. 